\title{
Kesalahan Morfologi pada Teks Eksplanasi Siswa SMA Negeri 7 Cirebon
}

Tati Sri Uswatia, ${ }^{a}$ dan Rina Maulindah ${ }^{a, b}$

aAIN Syekh Nurjati Cirebon, Indonesia

Itatisriuswati@gmail.com; ${ }^{2}$ rinamaulindah@gmail.com

\begin{tabular}{ll} 
Article info & A B S T R A C T \\
\hline Article history: & Explanatory texts are new subjects that are important for students \\
Revised : 06-10-2019 & to master, including the language system. This study aims to \\
Accepted: 10-12-2019 & describe the forms of morphological errors in the writing of \\
& explanatory essays in class XI students of SMAN 7 Cirebon in the \\
& academic year 2019/2020. The subject of this qualitative research \\
& was in the form of an explanatory text essay from class XI \\
& students of SMA Negeri 7 Cirebon. Data collected through a \\
& literature study. Data analysis uses document analysis by \\
& identifying, analyzing, and describing morphological errors in \\
& explanatory texts written by students. The results of this study \\
& indicate that of 58 explanatory texts, there were 296 cases, \\
& including 198 or $67 \%$ affixation writing errors, 12 or $4 \%$ writing \\
& reduplication errors and 86 or $29 \%$ writing \\
& composition/compounding errors.
\end{tabular}

Keywords: affixation writing explanatory text literature study morphological reduplication

Teks eksplanasi merupakan mata pelajaran baru yang penting untuk dikuasai siswa, termasuk sistem kebahasaannya. Penelitian ini bertujuan mendeskripsikan bentuk-bentuk kesalahan morfologi pada penulisan karangan eksplanasi siswa kelas XI SMAN 7 Cirebon tahun pelajaran 2019/2020. Subjek penelitian kualitatif ini berupa karangan teks eksplanasi siswa kelas XI SMA Negeri 7 Cirebon. Data dikumpulkan melalui studi pustaka. Analisis data menggunakan analisis dokumen dengan mengidentifikasi, menganalisis, dan mendeskripsikan kesalahan morfologi pada teks eksplanasi yang ditulis oleh siswa. Hasil penelitian ini menunjukkan bahwa dari 58 teks eksplanasi, terdapat 296 kasus, meliputi: 198 atau 67\% kesalahan penulisan afiksasi, 12 atau 4\% kesalahan penulisan reduplikasi, dan 86 atau 29\% kesalahan penulisan komposisi/pemajemukan.

Copyright @ 2019 Institut Agama Islam Negeri Syekh Nurjati Cirebon. All rights reserved.

\section{PENDAHULUAN}

Seperti yang dinyatakan Sugono (2009), bahasa bukan sekadar alat komunikasi, bahasa itu alat pikir dan alat ekspresi maka bahasa itu bersistem. Suatu keistimewaan dalam kurikulum 2013 adalah menempatkan bahasa Indonesia sebagai penghela ilmu pengetahuan (Mahsun, 2014). Salah satu pembahasan bahasa Indonesia berbasis teks dalam kurikulum 2013, yaitu teks eksplanasi yang diberikan pada kelas XI SMA dengan kompetensi dasar (KD) 4.4. Siswa dituntut untuk memiliki kompetensi memproduksi/menulis teks eksplanasi. 

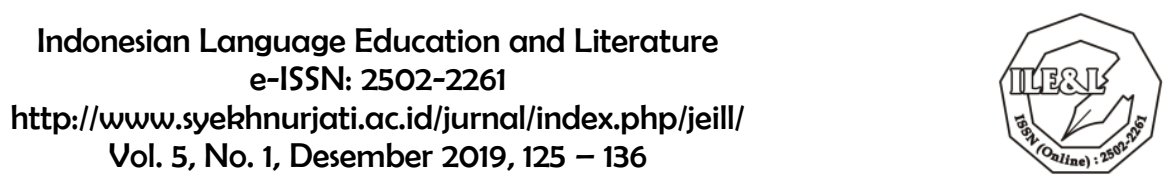

Keterampilan menyusun atau menulis teks banyak menemui kendala, khususnya menyusun teks eksplanasi apalagi jenis teks tersebut merupakan mata pelajaran baru yang penting untuk dikuasai peserta didik, sedangkan teks eksplanasi yang dinyatakan Priyatni (2014) adalah teks yang mengungkapkan paparan tentang proses yang terkait dengan fenomena-fenomena alam, sosial, ilmu budaya, dan yang lainnya. Teks eksplanasi berasal dari pertanyaan terkait mengapa dan bagaimana suatu peristiwa bisa terjadi. Senada dengan pendapat tersebut Restuti (2013) menyatakan bahwa teks eksplanasi merupakan teks yang menjelaskan proses atau fenomena alam dan sosial.

Sementara itu, Mahsun (2014) menjelaskan bahwa teks eksplanasi adalah jenis teks yang memiliki fungsi sosial menjelaskan atau menganalisis proses muncul atau terjadinya sesuatu. Teks eksplanasi berisi tentang keadaan sesuatu sebagai akibat dari sesuatu yang telah terjadi sebelumnya dan menyebabkan suatu peristiwa lain akan terjadi berikutnya. Pada teks eksplanasi, sebuah peristiwa timbul karena ada peristiwa lain sebelumnya dan peristiwa tersebut mengakibatkan peristiwa yang lain lagi sesudahnya (Maryanto, 2014). Menurut Sobandi (2014), kaidah teks eksplanasi kompleks ada tiga, yaitu: (1) berisi proses terjadinya, (2) bersifat kausal dan kronologis, serta (3) bahasa.

Berdasarkan uraian di atas, dapat disimpulkan bahwa teks eksplanasi merupakan salah satu jenis teks yang di dalamnya berisi tentang proses terjadinya suatu peristiwa baik peristiwa alam, non-alam maupun peristiwa sosial dan dalam teks tersebut sebab dan akibat dari suatu peristiwa dijelaskan secara detail. Dengan menyusun teks eksplanasi, peserta didik dituntut untuk menentukan topik sebuah peristiwa kemudian dikembangkan dengan penjelasan sesuai dengan fakta yang mendalam sehingga menjadi sebuah teks eksplanasi yang terstruktur.

Menulis sebuah teks eksplanasi yang terstruktur memerlukan keterampilan berbahasa tulis sebagai mediumnya. Seseorang yang dapat membuat suatu tulisan dengan baik berarti ia telah menguasai tata bahasa, memiliki perbendaharaan kata, dan mempunyai kemampuan menuangkan ide atau gagasan dalam bentuk tulisan. Dengan demikian, tulisan siswa dapat dijadikan sebagai salah satu tolok ukur keberhasilan siswa dalam pembelajaran bahasa Indonesia (Sukman, 2005). Morsey (dalam Tarigan, 1992) menyatakan bahwa menulis digunakan oleh orang terpelajar untuk mencatat, merekam, menyakinkan, melaporkan atau memberitahukan dan 

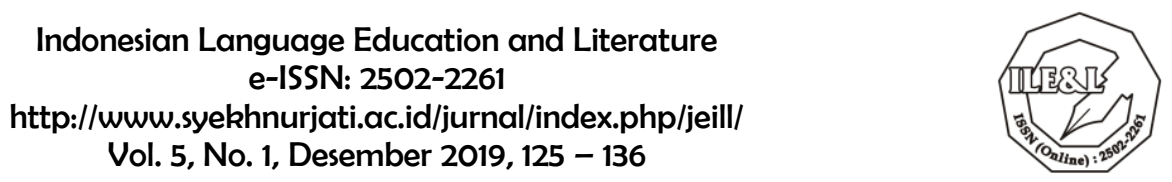

mempengaruhi, dan maksud serta tujuan seperti itu hanya dapat dicapai oleh orangorang yang dapat menyusun pikirannya dan mengutarakan dengan jelas. Namun, pada kenyataannya, mahasiswa pun masih belum sepenuhnya menghargai dan atau mengerti penggunaan bahasa Indonesia secara baik dan benar (Mulyaningsih, 2017). Pada sisi lain, hendaklah benar-benar disadari bahwa orang tidak dapat belajar bahasa tanpa sama sekali berbuat kesalahan- kesalahan secara sistematis.

Kesalahan berbahasa pada penelitian ini akan difokuskan pada hasil tulisan teks eksplanasi siswa SMA Negeri 7 Cirebon. Salah satu bentuk yang tepat untuk menganalisis kesalahan berbahasa pada karangan siswa adalah analisis kesalahan morfologi. Morfologi adalah ilmu mengenai bentuk-bentuk dan pembentukan kata (Chaer, 2015). Proses morfologis adalah proses pembentukan kata dari sebuah bentuk dasar melalui pembubuhan afiks (dalam proses afiksasi), pengulangan kata (dalam proses reduplikasi), dan penggabungan kata (dalam proses komposisi/pemajemukan). Jadi, pada penelitian ini akan dianalisis kesalahan proses morfologi pembentukan kata melalui proses afiksasi, reduplikasi, dan komposisi/pemajemukan.

Banyak penelitian tentang keterampilan menulis eksplanasi dan analisis morfologi. Sebagai contoh, penelitian prospektif oleh Jatnika, dkk (2014) yang menyimpulkan bahwa sistem morfologis bahasa pengiklanan memiliki bentuk fonemik spesifik dalam proses morfologisnya, bentuk morfemik spesifik dalam proses morfologisnya, morfem khusus yang secara khusus digunakan di bidang telepon seluler, proses morfologi spesifik, dan diksi khusus. Mereka adalah bentuk khas dari sistem morfologis bahasa iklan dalam layanan telepon seluler. Berikutnya penelitian yang dilakukan oleh Andayani, dkk (2018). Tujuan penelitian ini adalah untuk meningkatkan kualitas proses dan kemampuan menulis teks eskplanasi siswa melalui penggunaan media audio visual. Selain itu, penelitian oleh Darojat (2014). Subjek kajiannya adalah wacana Hidimbahidimbi. Objek kajiannya pada analisis afiksasi dan reduplikasi. Penelitian Uswati \& Nuryanto (2018) berobjek kajian kesalahan sintaksis. Hasil penelitian tersebut menunjukkan bahwa tidak hanya kesalahan sintaksis yang masih relatif besar, termasuk pula kesalahan penulisan yang terkait dengan ejaan dan morfologi. Penelitian Sutisna (2017) bersubjek kajian surat kabar Radar Majalengka dan berobjek kajian kesalahan penggunaan kata dan bentuk kata. Kesalahan didominasi oleh aspek morfologi bahasa Indonesia berupa afiksasi atau imbuhan. 

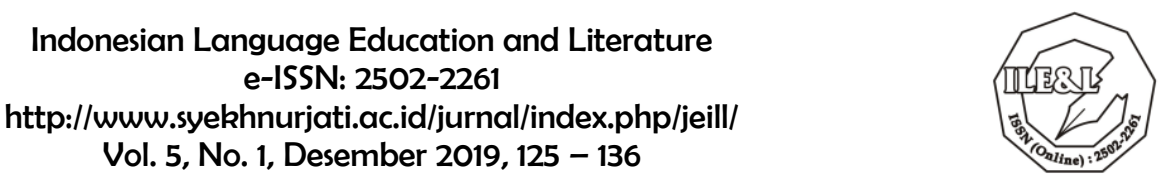

Kegiatan menulis merupakan bentuk atau wujud kemampuan dari keterampilan berbahasa yang paling akhir dikuasai pembelajar bahasa setelah menyimak, berbicara, dan membaca. Kejelasan dalam bahasa tulis merupakan keniscayaan. Hal ini seperti diungkapkan (Morsey, 1976; Tarigan, 2011) bahwa tulisan dipergunakan orang terpelajar untuk merekam, meyakinkan, melaporkan serta mempengaruhi orang lain; maksud serta tujuan itu akan tercapai apabila penulis dapat menyusun pikirannya serta mengutarakannya dengan jelas dan kejelasan tersebut bergantung pada pikiran, organisasi, penggunaan kata-kata, dan struktur kalimat yang cermat.

Analisis kesalahan berbahasa merupakan prosedur kerja yang biasa digunakan oleh peneliti atau guru bahasa yang meliputi: kegiatan mengumpulkan sampel kesalahan, mengidentifikasi kesalahan yang terdapat dalam sampel, menjelaskan kesalahan tersebut, mengklasifikasi kesalahan tersebut, dan mengevaluasi taraf keseriusan kesalahan itu. Terdapat tiga kemungkinan seseorang dapat salah dalam berbahasa, antara lain terpengaruh bahasa yang lebih dahulu dikuasainya (Setyawati, 2010). Kekurangpahaman pemakai bahasa terhadap bahasa yang dipakai. Pengajaran bahasa yang kurang tepat atau kurang sempurna. Afiksasi merupakan pemberian afiks pada sesuatu satuan, baik satuan itu berupa bentuk tunggal maupun bentuk kompleks untuk membentuk kata (Ramlan, 2001).

\section{METODE}

Metode penelitian adalah cara yang digunakan oleh peneliti dalam mengumpulkan data penelitiannya (Arikunto, 2013). Pendekatan kualitatif merupakan proses penelitian yang mendasarkan pada metodologi yang meneliti suatu fenomena sosial dan permasalahan manusia.” (Iskandar, 2009). Perumusan masalah pada penelitian kualitatif dilakukan secara induktif, berdasarkan data di lapangan (Putra, 2013).

Penelitian deskriptif kualitatif ini menggunakan rancangan studi kasus. Tujuan penelitian ini untuk mendeskripsikan kesalahan morfologi dalam penulisan teks eksplanasi siswa SMA Negeri 7 Cirebon tahun pelajaran 2019/2020 yang ditinjau dari bentuk kesalahan morfologi, yaitu kesalahan afiksasi, reduplikasi, dan komposisi/pemajemukan. Teknik pengumpulan data dengan menugasi siswa membuat karangan/teks eksplanasi. Hasil karangan siswa tidak dibedakan-bedakan. Siswa diminta menyusun teks eksplanasi paling sedikit 
empat paragraf. Data yang dianalisis adalah data yang sesuai dengan indikator penelitian yang telah dibuat, seperti tabel 1 .

\section{Tabel 1. Indikator Penelitian}

\begin{tabular}{|c|c|c|}
\hline No & Indikator & Deskripsi \\
\hline 1 & $\begin{array}{l}\text { Kesalahan Penulisan } \\
\text { Afiksasi }\end{array}$ & $\begin{array}{l}\text { Penyimpangan dalam pembubuhan afiks } \\
\text { pada sesuatu satuan (kata), baik satuan } \\
\text { itu berupa bentuk tunggal maupun bentuk } \\
\text { kompleks untuk membentuk kata. } \\
\text { Contoh kesalahan afiksasi, bentuk baku: } \\
\text { berlari ditulis ber lari. }\end{array}$ \\
\hline 2 & $\begin{array}{l}\text { Kesalahan Reduplikasi } \\
\text { (pengulangan kata) }\end{array}$ & $\begin{array}{l}\text { Penyimpangan penggunaan kata ulang } \\
\text { dengan cara mengulang bentuk dasar, } \\
\text { baik secara keseluruhan maupun } \\
\text { sebagian, baik disertai perubahan bunyi } \\
\text { atau tidak. Contoh kesalahan reduplikasi, } \\
\text { bentuk baku: mengelus-elus ditulis } \\
\text { mengelus-ngelus }\end{array}$ \\
\hline 3 & $\begin{array}{l}\text { Kesalahan Penulisan } \\
\text { Kompoisi/Kata Majemuk }\end{array}$ & $\begin{array}{l}\text { Penyimpangan penggunaan kata melalui } \\
\text { penggabungan atau pemaduan dua kata } \\
\text { dasar atau lebih sehingga menjadi satu } \\
\text { satuan makna. Contoh kesalahan } \\
\text { penulisan kata majemuk, bentuk baku: } \\
\text { rumah sakit ditulis rumahsakit. }\end{array}$ \\
\hline
\end{tabular}

Adapun langkah-langkah analisis datanya: 1) membaca dan memahami karangan siswa, 2) memberi penanda di kertas karangan siswa, kesalahan yang ditulis siswa pada saat menulis karangan, 3) mengidentifikasi, menganalisis, dan mendeskripsikan kesalahan morfologi yang meliputi kesalahan penulisan afiksasi, reduplikasi, dankomposisi/pemajemukan, 4) menghitung persentase kesalahan morfologi dari setiap jenis penyimpangan pada sampel yang diteliti, dengan menggunakan rumus yang telah dimodifikasi untuk kepentingan penelitian (Sudijono, 2010) dengan rumus:

$$
\mathrm{PSP}=\underline{\mathrm{SP}} \times 100 \% \mathrm{XP}
$$

Keterangan:

PSP : Persentase dari tiap jenis kesalahan morfologi dalam sampel.

SP : Jumlah kesalahan dari tiap jenis penyimpangan bidang morfologi dalam sampel.

XP : Jumlah penggunaan kata yang digunakan. 
5) menghitung persentase kesalahan morfologi secara keseluruhan (Sudijono, 2010) dengan rumus:

$$
\mathrm{PSK}=\mathrm{SK} \times 100 \% \mathrm{XK}
$$

Keterangan:

PSK : Jumlah persentase penyimpangan keseluruhan.

SK : Jumlah seluruh penyimpangan dari tiap jenis penyimpangan bidang morfologi

XK : Jumlah penggunaan kata seluruhnya.

6) menentukan penyimpangan penulisan bidang morfologi mana yang banyak dilakukan oleh siswa pada saat mengarang karangan deskripsi, 7) membahas hasil analisis, dan 8) membuat simpulan hasil analisis data.

\section{ANALISIS DAN HASIL PENELITIAN}

Hasil penelitian dapat diuraikan sebagai berikut. Data dalam penelitian ini berupa 58 tulisan teks eksplanasi siswa kelas XI SMA Negeri 7 Kota Cirebon tahun pelajaran 2019/2020 dari lima kelas, yaitu tiga kelas IPA (XI IPA 1, XI IPA 2, XI IPA 3, XI IPS 1, dan XI IPS 3) untuk mendapatkan data yang berhubungan dengan kesalahan morfologi, yakni kesalahan penulisan afiksasi, reduplikasi, dan komposisi. Objek kajiannya disesuaikan dengan rumusan masalah dalam penelitian, yaitu mendeskripsikan kesalahan morfologi yang meliputi kesalahan penulisan afiksasi, reduplikasi, dan komposisi/pemajemukan.

Jumlah keseluruhan kalimat yang mengandung kesalahan morfologi dari 58 teks eksplanasi siswa adalah sebanyak 171 kalimat dengan 296 kasus kesalahan. Adapun pendeskripsian secara keseluruhan dapat dilihat dalam distribusi kesalahan penulisan morfologi dan contoh pendeskripsiannya pada tabel 2.

\section{Kesalahan Penulisan Afiksasi}

Klasifikasi kesalahan penulisan afiksasi yang terbanyak pada penulisan teks eksplanasi siswa SMA Negeri 7 Cirebon, meliputi (1) penulisan preposisi yang ditulis serangkai seperti afiks, contohnya preposisi di dan ke pada di tempat, di atas, di asia, di TKP, di antara, di depan, dan ke belakang ditulis menjadi ditempat, diatas, diasia, diTKP, diantara, diTol, dan didepan, dan kebelakang. Berikutnya adalah (2) penulisan prefiks yang dipisah seperti penulisan preposisi, contohnya dikendarai, diyakini, dan sebuah ditulis terpisah menjadi di kendarai, 


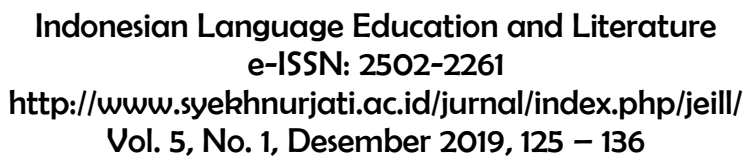

di yakini, dan se buah. Kesalahan selanjutnya (3) adalah penulisan afiks/kata yang tidak sesuai dengan kaidah pemenggalan kata karena tidak menggunakan tanda hubung ketika pergantian baris, seharusnya remnya, kendaraan, kecepatan, dan antrean, tetapi pada teks eksplanasi siswa tertulis rem nya, kenda raan, kece patan, dan antri an. (4) terdapat pula penulisan kata berafiks yang tidak benar; seharusnya ditulis digalakkan, terelakkan, temannya, dan menunjukkan, tetapi ditulis digalakan, terelakan, temanya, dan menunjukan. Di samping itu (5) ditemukan pula kesalahan penggunaan afiks yang tidak tepat karena menyebabkan makna kalimat menjadi tidak logis, seharusnya mengakibatkan mobil terguling; tertulis mengakibatkan mobil mengguling; demikian pula seharusnya dilarikan di empat rumah sakit, tetapi tertulis dilarikan keempat rumah sakit. Klasifikasi terakhir (6) adalah kesalahan penulisan kata berafiks yang tidak baku, yang baku adalah terserempet, menyerempet, dan menyalib, tetapi yang tertulis adalah keseremped, menseremped, dan mensalib.

\section{Kesalahan Penulisan Reduplikasi}

Klasifikasi kesalahan penulisan reduplikasi meliputi (1) kesalahan penulisan kata ulang yang masih menggunakan ejaan/gaya lama; yang tepat luka-luka, hatiluka, bangunan-bangunan, dan fasilitas-fasilitas; yang tertulis adalah luka2, hati2, bangunan2, dan fasilitas2. Kesalahan berikutnya (2) adalah penulisan kata ulang yang tidak menempatkan tanda hubung di antara bentuk ulang tersebut. Bentuk yang benar adalah berhati-hati, kendaraan-kendaraan, dan luka-luka, tetapi yang tertulis berhati hati, kendaraan kendaraan, dan luka luka. Kesalahan (3) berikutnya adalah kesalahan/ketidaktepatan penggunaan kata biasa yang semestinya menggunakan kata ulang karena terkait makna kalimat, misalnya pada kalimat Sekurangnya 21 kendaraan berbagai jenis terlibat dalam tabrakan beruntun itu, seharusnya yang benar adalah Sekurang-kurangnya 21 kendaraan berbagai jenis terlibat dalam tabrakan beruntun itu. 


\begin{tabular}{ll}
\hline No. & \multicolumn{1}{c}{ Kalimat/Klausa } \\
\hline $1 . \quad$ & $\begin{array}{l}\text { Sebenarnya narkoba memiliki manfaat } \\
\text { yang sangat berguna dalam bidang } \\
\text { medis namun kebanyakan disalah } \\
\text { gunakan } .\end{array}$ \\
& $\begin{array}{l}\text { Sebelum kecelakaan truck tsb menelpon } \\
\text { temannya bahwa remnya blong. }\end{array}$
\end{tabular}

3. Tempat-tempat yang berbata san $\underline{\mathrm{dgn}}$ laut dan rawan terjadi gempa memiliki potensi yg besar terkena tsunami ini, salah satunya Indonesia.

4. Tetapi karena truknya kelebihan muatan membuat truknya sulit untuk $d i$ hentikan.

5. Sehingga truk (S) menabrak 15 mobil yang terhenti didepannya.

6. Mobil tersebut melaju dengan sangat cepat sehingga menseremped mobilmobil yang terkena kemacetan tadi.

7. Keserempet mengenai atau menyentuh sedikit pada bidang yang agak memanjang ...

8. Awal mulanya sebuah dum truk dengan kecepatan yang sangat tinggi mengalami remblong yang mengakibatkan dum truk terguling dan sang supir meninggal ditempat

9. Pada kecelakaan ini ada hikmah yang dapat kita ambil yaitu berhati hatilah dalam mengemudi.
- Komposisi salah guna apabila dilekati prefiks
harus ditulis serangkai menjadi disalahgunakan.

Pembenahan kalimat:

Sebenarnya narkoba memiliki manfaat yang sangat berguna dalam bidang medis namun kebanyakan disalahgunakan .

-Agar hubungannya logis, seyogyanya menggunakan bentuk komposisi sopir truk_sehingga menjadi sebelum kecelakaan, sopir truk tersebut menelepon temannya bahwa remnya blong.

-Penyukuan kata pada kata berimbuhan hendaknya disesuaikan dengan proses afiksasinya, bukan berbata san, tetapi berbatas an.

Pembenahan kalimat:

Tempat-tempat yang berbatasan dengan laut dan rawan terjadi gempa, memiliki potensi yang besar terkena tsunami, salah satunya Indonesia.

di- pada di hentikan adalah prefiks. Jadi,harus ditulis serangkai menjadi dihentikan.

Pembenahan kalimat:

Namun, karena truknya kelebihan muatan sehingga sulit dihentikan

- Berdasarkan konteks kalimat, kelima belas mobil tersebut sengaja menghentikan kendaraannya.Jadi, seharusnya mengunakan prefis ber- bukan ter-. Karena ter- pada konteks tersebut menyatakan ketidaksengajaan.

- di- pada didepannya adalah preposisi. Jadi,harus ditulis terpisah menjadi di depannya.

- Penulisan lambang bilangan hendaknya ditulis dengan kata/huruf apabila hanya satu atau dua kata. Jadi, 15 seharusnya ditulis dalam bentuk komposisi lima belas.

Pembenahan kalimat:

Sehingga truk (S) menabrak lima belas mobil yang berhenti di depannya.

Bila dibubuhi awalan/prefiks meN- akan terjadi perubahan pada huruf awal kata dasar; yang akan mengalami perubahan adalah huruf $k, p, t, s$ yakni akan luluh/lebur. Awalan meberubah menjadi meny-, jika me-+kata dasar dengan huruf awal $s$ yang diikuti huruf vokal. Jadi, kata dasar serempet menjadi menyerempet, bukan menseremped.

Pembenahan kalimat:

Mobil tersebut melaju dengan sangat cepat sehingga menyerempet mobil-mobil yang terkena kemacetan tadi. Keserempet adalah kata dari bahasa jawa. Penggunaan prefiks ter- menjadi Terserempet lebih tepat dan baku.

Pembenahan kalimat:

Terserempet mengenai atau menyentuh sedikit pada bidang yang agak memanjang ...

- Komposisi yang baku seharusnya dump truck.

- Remblong seharusnya ditulis terpisah rem blong karena merupakan dua kata.

- Di pada didepannya bukanlah prefiks, melainkan preposisi sehingga penulisannya harus dipisah menjadi $d i$ depannnya.

Pembenahan kalimat:

Awal mulanya sebuah dump truck dengan kecepatan yang sangat tinggi mengalami rem blong yang mengakibatkan dump truck terguling dan sang sopir meninggal di tempat Sesuai dengan kaidah PUEBI, penulisan reduplikasi antarunsur-unsurnya harus dibubuhi tanda hubung sehingga menjadi berhati-hatilah.

Pembenahan kalimat:

Pada kecelakaan ini ada hikmah yang dapat kita ambil, yaitu berhati-hatilah dalam mengemudi.

$D i$ pada diasia bukan prefiks, melainkan preposisi sehingga penulisannya harus dipisah menjadi di Asia. 
pengedar narkoba terbesar diasia.

11. Kejadian tersebut terjadi dari dump truck yang bermuatan \pm 37 ton terguling dikarenakan rem blong.

12. Dump truck yang terguling awalnya menelpon temannya mengasih tau_kalau remnya blong.

13. Tsunami terjadi ketika ada gerakan vertikal pada kerak bumi baik karena diakibatkan meletusnya gunung api, gempa bumi, longsor hingga meteor yg jatuh kelaut.

Tidak hanya bangunan2 dan fasilitas2 saja, bencana ini juga menelan banyak korban jiwa.

15. Pada awalnya truk yang di kendarai (DH) menyalip truk yang dikendarai oleh (S) dengan kecepatan tinggi.

16 Namun sayangnya ban mobil truk meletus dan mengakibatkan mobil mengguling dan menyebabkan $\underline{\text { supir }}$ tewas ditempat.

17. Maka dari itu kita harus berhati hati dalam berkendara dan patuhi cara berkendara yang telah ada diperaturan kendaraan.

18. Kita harus berada diantara matahari dan tetesan air dgn matahari di belakang kita.

19. Kekeringan adalah suatu kondisi dimana ketersediaan air disuatu tempat sangat rendah bahkan tidak tersedia sama sekali yang terjadi dalam kurun waktu yang cukup lama.

\section{Pembenahan kalimat:}

Mirisnya, Indonesia adalah pasar bandar pengedar narkoba terbesar di asia.

Komposisi yang baku seharusnya dicetak miring dump truck.

- Afiks di---kan pada kata karena tidak tepat, seharusnya disebabkan karena dikarenakan tidak resmi/ragam cakapan.

Pembenahan kalimat:

Peristiwa tersebut terjadi karena dump truck yang bermuatan \pm 37 ton terguling disebabkan remnya blong.

Komposisi yang baku seharusnya memberi tahu karena mengasih tahu merupakan ragam cakapan

Pembenahan kalimat

- Dump truck yang terguling, awalnya, menelepon temannya untuk memberi tahu bahwa remnya blong.

- Jika dilihat dari makna konteks, komposisi gunung berapi lebih tepat daripada gunung api.

- Ke pada kelaut bukan prefiks, melainkan preposisi, jadi seharusnya ditulis terpisah menjadi ke laut.

Pembenahan kalimat:

Tsunami terjadi ketika ada gerakan vertikal pada kerak bumi baik karena diakibatkan meletusnya gunung berapi, gempa bumi, longsor, maupun meteor yang jatuh ke laut.

Penulisan reduplikasi bangunan2 dan fasilitas2 tidak baku;sesuai kaidah PUEBI, yang baku adalah bangunanbangunan dan fasilitas-fasilitas.

Pembenahan kalimat:

Tidak hanya bangunan-bangunan dan fasilitas-fasilitas saja, bencana ini juga menelan banyak korban jiwa.

di- pada di kendarai adalah prefiks. Jadi, harus ditulis serangkai menjadi dikendarai.

Pembenahan kalimat:

Pada awalnya truk yang dikendarai (DH) menyalip truk yang dikendarai oleh (S) dengan kecepatan tinggi.

- Makna prefiks meng- pada kalimat tersebut berarti 'sengaja'. Padahal berdasarkan konteks kalimat, peristiwa kecelakaan tersebut akibat faktor ketidaksengajaan. Akan lebih tepat bila menggunakan prefiks ter- karena prefiks ter-pada konteks tersebut bila diikuti guling menyatakan makna tidak sengaja.

- di- pada ditempat bukan prefiks, melainkan preposisi. Jadi,harus ditulis terpisah menjadi di tempat.

Pembenahan kalimat:

Namun, sayangnya ban mobil truk meletus mengakibatkan mobil tersebut terguling dan menyebabkan sopir tewas di tempat.

- Sesuai dengan kaidah PUEBI, pada penulisan reduplikasi, antarunsur-unsurnya harus dibubuhi tanda hubung sehingga menjadi berhati-hati.

- Di pada diperaturan bukanlah prefiks, melainkan preposisi sehingga penulisannya harus dipisah. Namun, fungsi preposisi $d i$ adalah untuk menyatakan makna tempat. Berdasarkan konteks tersebut, preposisi yang lebih tepat digunakan adalah pada.

Pembenahan kalimat:

Maka dari itu, kita harus berhati-hati dalam berkendara dan patuhi cara berkendara yang telah ada pada peraturan lalu lintas

Di pada diantara bukanlah prefiks, melainkan preposisi sehingga penulisannya harus dipisah menjadi di antara. Pembenahan kalimat:

Kita harus berada di antara matahari dan tetesan air dengan matahari di belakang kita.

Di pada dimana dan disuatu bukanlah prefiks, melainkan preposisi sehingga penulisannya harus dipisah. Di samping itu, penggunaan kata tanya tempat di mana pada konteks tersebut kurang tepat karena tidak sesuai dengan fungsinya. Akan lebih tepat kalau menggunakan konjungsi karena. 
20. Untuk faktor alam misalnya terjadi kemarau yang berkepanjang dan tingkat evaporasi yang sangat cepat yang mengakibatkan cadangan air didalam tanah menjadi cepat hilang.

21 Dump truk tersebut mensalib 15 kendaraan yang berada diblakang truk temannya yang terguling.

22. Akhirnya dari kecelakaan beruntun tersebut mengakibatkannya banyak korban.

Oleh karena itu semua pengemudi diharapkan untuk memperlambat kendaraan dalam medan yang menurun dan menggunakan kecepatan yang seharusnya guna menghindarkan kecelakaan seperti ini.

24.. Ada mobil yang terkena serempedan langsung meledak, setelah itu mobil 2 itu bertambah kehilangan kendali dengan menelindas mobil yang ada didepannya.

\section{Pembenahan kalimat:}

Kekeringan adalah suatu kondisi karena ketersediaan air di suatu tempat sangat rendah bahkan tidak tersedia sama sekali yang terjadi dalam kurun waktu yang cukup lama.

- Prefiks ber- pada kata berkepanjang tidak lazim; yang sesuai adalah berkepanjangan.

- Di pada didalam bukanlah prefiks, melainkan preposisi sehingga penulisannya harus dipisah menjadi di dalam.

Pembenahan kalimat:

Untuk faktor alam, misalnya terjadi kemarau yang berkepanjangan dan tingkat evaporasi yang sangat cepat mengakibatkan cadangan air di dalam tanah menjadi cepat hilang

- Bila dibubuhi awalan/prefiks meN- akan terjadi perubahan pada huruf awal kata dasar; yang akan mengalami perubahan adalah huruf $k, p, t, s$ yakni akan luluh/lebur. Awalan me- berubah menjadi meny-, jika me-+kata dasar dengan huruf awal s yang diikuti huruf vokal. Jadi, kata dasar salip menjadi menyalip, bukan mensalib.

- Karena kata asing, komposisi dump truk seharusnya ditulis dengan cetak miring menjadi dump truck.

- Penulisan lambang bilangan hendaknya ditulis dengan kata/huruf apabila hanya satu atau dua kata. Jadi, 15 seharusnya ditulis dalam bentuk komposisi lima belas.

- Pembenahan kalimat:

Dump truck tersebut menyalip lima belas kendaraan yang berada di belakang truk temannya yang terguling.

Penggunaan -nya pada mengakibatkannya tidak berterima. Jadi, sebaiknya - nya dihilangkan menjadi mengakibatkan.

Pembenahan kalimat:

Akhirnya kecelakaan beruntun tersebut mengakibatkan banyak korban.

- memper- pada kata memperlambat menyatakan makna menyebabkan jadi. Berdasarkan konteks kalimat, makna tersebut kurang tepat. Akan lebih sesuai jika menggunakan afiks me---kan sehingga menjadi melambatkan yang menyatakan melakukan pekerjaan dan ada kesejajaran dengan menggunakan.

- Pada kata kendaraan seharusnya dibubuhi klitika -nya agar lebih tepat karena mengacu pada mereka.

Pembenahan kalimat:

Oleh karena itu, semua pengemudi diharapkan melambatkan kendaraannya dalam medan yang menurun dan menggunakan kecepatan yang seharusnya guna menghindarkan kecelakaan seperti ini

- Serempedan tidak baku dan tidak tidak tepat digunakan dalam konteks tersebut; akan lebih efektif jika terkena serempedan diubah menjadi terserempet karena makna ter-pada konteks tersebut menyatakan tidak sengaja.

- Berdasarkan makna konteks yang tepat bukan mobil 2, tetapi kedua mobil karena menyatakan kumpulan dengan membubuhkan prefiks ke- pada dua menjadi kedua.

- Menelindas tidak lazim karena dari kata dasar lindas dengan huruf awal $l$ apabila dilekati prefiks $m e N$ - akan terjadi penghilangan fonem menjadi melindas.

- Di pada didepannya bukanlah prefiks, melainkan preposisi sehingga penulisannya harus dipisah menjadi $d i$ depannnya.

Pembenahan kalimat:

Ada mobil yang terserempet langsung meledak, setelah itu kedua mobil tersebut semakin kehilangan kendali dengan menabrak mobil yang ada di depannya. 


\section{Kesalahan Penulisan Komposisi/Pemajemukan}

Klasifikasi kesalahan penulisan komposisi/pemajemukan meliputi (1) Penulisan komposisi kata dan kata yang tidak baku/terpengaruh ragam cakapan; seharusnya memberi tahu, sopir truk ditulis mengasih tahu, supir truk (2) penulisan komposisi yang tidak tepat, seharusnya dipisah rem blong, tetapi disatukan menjadi remblong. Berikutnya (3) adalah kesalahan komposisi yang tidak sesuai dengan PUEBI, yaitu (3a) komposisi dari bahasa asing yang seharusnya dicetak miring dump truck, tetapi ditulis tegak "dump truck"; demikian pula (3b) penulisan komposisi berupa lambang bilangan yang seharusnya ditulis dengan kata empat belas, lima belas, tetapi ditulis dengan angka 14 dan 15 . Terakhir (3c) kesalahan penulisan komposisi berafiks yang tidak tepat; seharusnya disalahgunakan ditulis disalah gunakan.

\section{SIMPULAN}

Berdasarkan hasil analisis, dari 58 teks eksplanasi yang ditulis oleh siswa, terdapat 171 kalimat yang teridentifikasi adanya kesalahan penulisan afiksasi, reduplikasi, dan atau komposisi/pemajemukan dengan 296 kasus kesalahan, yaitu 198 atau $67 \%$ kesalahan penulisan afiksasi, 12 atau 4\% kesalahan penulisan reduplikasi, dan 86 atau 29\% kesalahan penulisan komposisi/pemajemukan.

\section{UCAPAN TERIMA KASIH}

Terima kasih disampaikan kepada Kementerian Agama melalui IAIN Syekh Nurjati Cirebon karena telah membantu penelitian ini dengan memberikan Dana Bantuan Penelitian Tahun 2019.

\section{DAFTAR PUSTAKA}

Andayani, A., dkk. (2018). Peningkatan Kemampuan Menulis Teks Eksplanasi dengan Menggunakan Media Audiovisual pada Siswa Sekolah Menengah Pertama. BASASTRA Jurnal Penelitian Bahasa, Sastra Indonesia dan Pengajarannya, 4(2).

Arikunto, S. (2013). Proses Penelitian Suatu Pendekatan Praktik. Jakarta: Rineka Cipta.

Chaer, A. (2015). Morfologi Bahasa Indonesia. Jakarta: PT Rineka Cipta. 
Darojat, K. (2014). Kajian Morfologis dalam Wacana Hidimbahidimbi. Yogyakarta: Universitas Negeri Yogyakarta.

Iskandar. (2009). Metode Penelitian Kualitatif. Jakarta: Gaung Persada.

Jatnika, dkk. (2014). 'Typical ' Morphology System of Language Advertising of Cellular Services. International Journal of Linguistics, 6(3).

Mahsun. (2014). Metode Penelitian Bahasa: Tahapan Strategi, Metode dan Tekniknya. Jakarta: Rejawali Pers.

Mulyaningsih, I. (2017). Sikap Mahasiswa terhadap Bahasa Indonesia. Indonesian Language Education and Literature, 3(1), 79 - 87. DOI. http://dx.doi.org/10.24235/ileal.v3i1.1525.

Priyatni, E.T. (2014). Desain Pembelajaran Bahasa Indonesia dalam Kurikulum 2013. Jakarta: Bumi Aksara.

Putra, N. (2013). Metode Penelitian Kualitatif Pendidikan. Jakarta: Grafindo.

Ramlan, M. (2001). Morfologi: Suatu Tindakan Deskriptif. Yogyakarta: C.V. Haryono.

Restuti. (2013). Mandiri Bahasa Indonesia. Jakarta: Erlangga.

Setyawati, N. (2010). Analisis Kesalahan Berbahasa Indonesia. Surakarta: Yuma Pressindo.

Sudijono, A. (2010). Pengantar Statistik Pendidikan. Jakarta: Grafindo Persada.

Sugono, D. (2009). Mahir Berbahasa Indonesia Dengan Benar. Jakarta: Gramedia.

Sukman. (2005). Menumbuhkan Budaya Menulis di Kalangan Siswa. Buletin dan Pusat Pembukuan, 11. Jakarta: Pusat Perbukuan

Sutisna, D. (2017). Analisis Kesalahan Morfologi Bahasa Indonesia dalam Surat Kabar Radar Majalengka. Diglosia-Jurnal Pendidikan, Kebahasaan, dan Kesusastraan Indonesia, 1(1).

Tarigan, H.G. (1992). Menulis: sebagai Suatu Keterampilan Berbahasa. Bandung: Angkasa.

Tarigan, H.G. (2011). Pengajaran Analisis Kesalahan Berbahasa. Bandung: Angkasa.

Uswati, T.S. \& Nuryanto, T. (2018). Kesalahan Sintaksis pada Skripsi Mahasiswa IAIN Syekh Nurjati Cirebon. Jurnal Indonesian Language Education and Literature, 4(1), $1-10$. 